\title{
Population dynamics, response to sedimentation and role in benthic metabolism of the amphipod Monoporeia affinis in an open-sea area of the northern Baltic Sea
}

\author{
Kari K. Lehtonen*, Ann-Britt Andersin \\ Finnish Institute of Marine Research, PO Box 33, FIN-00931, Helsinki, Finland
}

\begin{abstract}
Population dynamics of the benthic, deposit-feeding amphipod Monoporeia affinis was studied over 3 spring bloom periods (1991 to 1993) at a deep (125 m), northern Baltic (Bothnian Sea) open-sea station. Simultaneously recorded sedimentation data (1991 and 1993) were used to investigate pelagic-benthic coupling that is believed to regulate the growth of the amphipod population. Growth of individuals and population biomass both showed a distinct response to the sedimentation of the spring bloom after, approximately, a $4 \mathrm{wk}$ time lag. Thus, the dynamics of the amphipod population seems to be tightly coupled to the autochthonous food source. Using parallel metabolic and body composition data, the instantaneous and annual requirements of carbon and nitrogen (production, respiration and nitrogen excretion) of the population were calculated. The results showed that the role of the amphipod population in benthic mineralization of organic matter is probably highly significant in the study area. Moreover, the results implied that local primary production and the measured sedimentation rates at the location cannot provide the benthos with sufficient food. This suggests that resuspension and the lateral transport of organic particulates from adjacent sea areas play a critical role in supporting the amphipod population in the study area. In addition to strong seasonal variability in growth of the amphipods, marked interannual variability was observed in the other population parameters measured. Biomass, density and annual production rates of the population all showed a marked decreasing trend during the study period. Marked interannual variation in the recruitment success (survival of the offspring) of the different annual cohorts also seemed to show density-and/or nutritiondependency. This study also corroborates previously recorded long-term fluctuations (ca 7 yr cycle) in amphipod populations in the Bothnian Sea and reveals the possible factors causing these fluctuations.
\end{abstract}

KEY WORDS: Baltic Sea Benthıc amphipod - Metabolism - Mineralization - Monoporeia affinis Pelagic-benthic coupling - Population dynamics - Sedimentation

\section{INTRODUCTION}

The amphipod Monoporeia affinis (formerly Pontoporeia affinis; see Bousfield 1989) dominates the macrozoobenthos in the species-poor northern Baltic Sea softbottoms, reaching densities of 10000 ind. $\mathrm{m}^{-2}$ and more (e.g. Ankar \& Elmgren 1975, Andersin et al. 1978, 1984, Elmgren 1978). In these areas, the species has a key role with regard to energy flow and plays an important part in the organization and functioning of the ecosys-

•E-mail: lehtonen@fimr.fi tem. Extensive studies on the general biology of $M$. affinis have been published (e.g. Segerstråle 1937, Andersin et al. 1984, Sarvala 1986, Uitto \& Sarvala 1991).

Monoporeia affinis is semelparous, reproducing usually in early spring, with a life-cycle varying between 1 and 4 yr (e.g. Segerstråle 1937, Andersin et al. 1984, Leonardsson et al. 1988). The amphipod feeds mainly on detrital organic matter and sedimented phytoplankton, and is therefore strongly dependent on the nutritional composition of the sediment surface layer In the northern Baltic open-sea areas, the major sedimentation event occurs during and just after the 5 to $6 \mathrm{wk}$ of 
the spring phytoplankton bloom, while at other times the vertical input is small (e.g. Kuparinen et al. 1984, Leppänen 1988). This type of sedimentation pattern generates strong seasonal variations in the availability of good quality food, and it has been suggested that the bioenergetic strategy of $M$. affinis is modified by geographically varying environmental conditions (Lehtonen 1995, 1996a, b).

The density and biomass of Monoporeia affinis populations show substantial spatial, seasonal and interannual variations (Andersin et al. 1978, 1984). Evidence of a coupling between the intensity of algal blooms and the density and biomass of benthic amphipod populations has been obtained from lakes (Johnson \& Wiederholm 1992, Fitzgerald \& Gardner 1993) and. from coastal areas of the Baltic Sea (Cederwall 1977, Elmgren 1978, Sarvala 1986).

In areas where the density of benthic macrofauna is high, animal metabolism contributes a marked portion to the mineralization of organic matter. The role of Monoporeia affinis in benthic respiration has been shown to be important in a coastal region of the northern Baltic Sea (Bergstrom \& Sarvala 1986). The potential contribution of amphipods to benthic nitrogen mineralization after the spring bloom has been estimated in different parts of the Baltic Sea (Lehtonen 1995); moreover, in the Gulf of Riga, the total annual nitrogen release has been estimated (Lehtonen unpubl.).

The goals of this study were to examine (1) the population dynamics of an open-sea population of Monoporeia affinis, (2) the effects of environmental nutritional factors, mainly sedimentation, on the population, and (3) the role of the amphipods in benthic mineralization processes. The study was carried out in the Bothnian Sea (northern Baltic Sea) during 1991 to 1993 and covered 3 spring bloom periods; thus, in addition to seasonal coverage, interannual comparisons were possible. Advantage was taken of parallel studies on the metabolism (Lehtonen 1996b) and body composition (Lehtonen 1996a) of amphipods, and of original data on primary production in the area in 1991 (Andersson et al. 1996). The studies were initiated under the Finnish-Swedish cooperation framework 'Gulf of Bothnia Year 1991'.

\section{MATERIAL AND METHODS}

Sampling and morphometric measurements. Monoporeia affinis were collected at different seasons between 16 January 1991 and 28 July 1993 at the Both-
Table 1. Monoporeia affinis. The sampling scheme, 1991 to 1993

\begin{tabular}{|c|c|c|c|c|}
\hline Date & & $\begin{array}{l}\text { Population samples } \\
\text { (This study) }\end{array}$ & $\begin{array}{c}\text { Biochemistry } \\
\text { (Lehtonen 1996a) }\end{array}$ & $\begin{array}{c}\text { Metabolism } \\
\text { (Lehtonen 1996b) }\end{array}$ \\
\hline \multirow[t]{9}{*}{1991} & $16 \mathrm{Jan}$ & - & - & - \\
\hline & $03 \mathrm{Mar}$ & - & - & - \\
\hline & $16 \mathrm{Apr}$ & - & - & \\
\hline & 07 May & - & - & - \\
\hline & 22 May & • & & \\
\hline & 17 Jun & - & - & - \\
\hline & $13 \mathrm{Aug}$ & - & - & \\
\hline & 24 Sep & • & - & \\
\hline & $12 \mathrm{Dec}$ & - & - & - \\
\hline \multirow[t]{6}{*}{1992} & $03 \mathrm{Mar}$ & - & - & - \\
\hline & $06 \mathrm{May}$ & - & & \\
\hline & 28 May & - & - & - \\
\hline & 16 Jun & - & - & - \\
\hline & $09 \mathrm{Sep}$ & - & & \\
\hline & 25 Nov & - & - & • \\
\hline \multirow[t]{3}{*}{1993} & $04 \mathrm{Mar}$ & - & - & - \\
\hline & 27 May & - & - & - \\
\hline & $28 \mathrm{Jul}$ & - & - & \\
\hline
\end{tabular}

nian Sea (northern Baltic Sea) open-sea station SR5 $\left(61^{\circ} 05^{\prime} \mathrm{N}, 19^{\circ} 35^{\prime} \mathrm{E}\right.$, depth $125 \mathrm{~m}$ ) (Table 1). Samples were obtained using a modified Olauson box corer with a biting area of $400 \mathrm{~cm}^{2}$ (Andersin et al. 1986). At each sampling occasion 5 samples were taken and sieved through 1.0 and $0.5 \mathrm{~mm}$ meshes. The organisms were stored in 5\% formalin solution containing hexamin as buffer Species composition, abundance and biomass (formalin wet wt) were determined from 4 samples. The body length (from the end of the rostrum to the tip of the telson) of $M$. affinis was determined from 4 samples with the accuracy of $0.17 \mathrm{~mm}$, using an ocular micrometer ( $6 \times$ magnification). From 1 or 2 samples, biomass (wet and dry wt) was determined for each $1 \mathrm{~mm}$ length class. For size distributions, a 3-value floating average was used and the amphipods were divided into year classes (cohorts). Using the average length and mean biomass per individual in each length class, length-weight regressions $D W=a L^{b}$ [DW $=$ formalin dry weight $(\mathrm{mg})$, and $L=$ length $(\mathrm{mm})$ ] were calculated for each sampling occasion (Table 2). Population biomass values were calculated by using the actual size distributions and the length-weight regression equations. The formalin DW were corrected to lyophilized DW by multiplying by the empirical factor 1.58 (Table 3; see below).

In connection with zoobenthos sampling, temperature, salinity and oxygen conditions in the near-bottom water (see Fig. 1) were analyzed according to the methods described in the Guidelines for the Baltic Monitoring Programme of the Helsinki Commission (Anonymous 1988).

Comparison of weight determination methods. The common practice of using formalin DW was not con- 
Table 2. Monoporeia affinis. Seasonal variation in the parameters of the length-weight regressions $D W=a \times L^{b}$, where $D W=$ formalin dry wt $(\mathrm{mg})$, and $L=$ length (mm). n: number of individuals measured, $\mathrm{r}^{2}=$ coefficient of determination

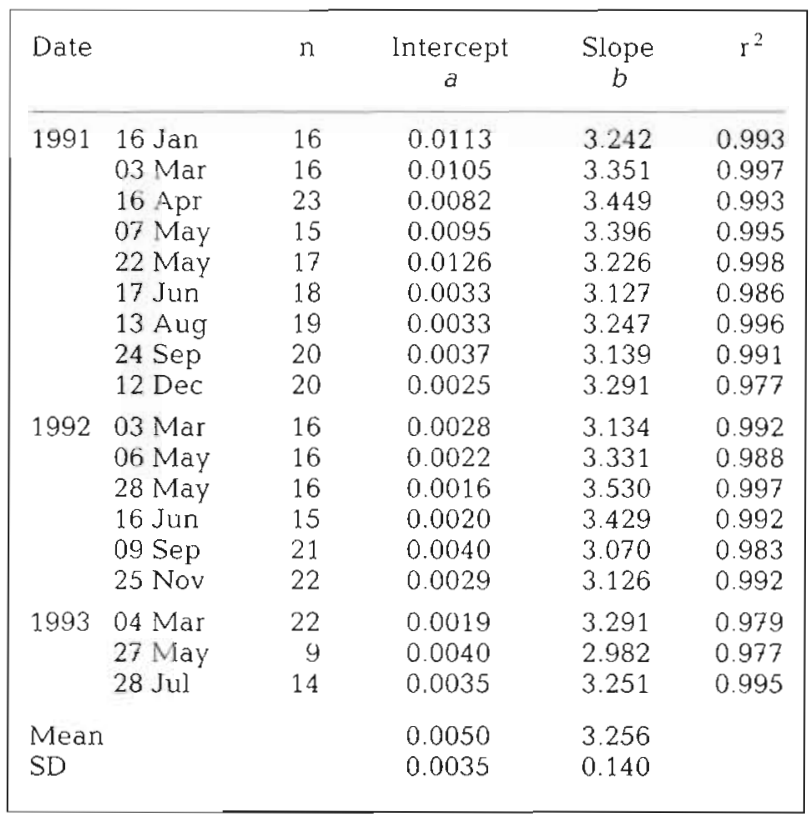

sidered valid for the biomass estimations, since the extensive lipid stores of Monoporeia affinis (Hill et al. 1992, Lehtonen 1996a; up to $44 \%$ of DW) are likely to leak into the formalin solution during prolonged storage, causing a serious downward bias of DW. To solve this problem, a comparison was made between different methods of weight determination (Table 3).
Reproductive output and cohort dynamics. Theoretical annual reproductive output of the amphipod population was calculated by multiplying the number of gravid females by the mean number of eggs per individual of corresponding size. The number of eggs per gravid female was obtained in November 1990; a positive correlation between length and number of eggs was observed. Since no $10 \mathrm{~mm}$ females were found in 1991, the number of eggs produced by this size class, present in 1992 and 1993, was estimated by using a linear regression between the body size $(x, \mathrm{~mm}$ length classes) and the egg number ( $y$, mean for each mm length class) of the ovigerous females, giving the equation $y=3.2 x-6.43\left(n=3, r^{2}=0.96\right)$.

Metabolism, body composition and production. Seasonal data on metabolism [oxygen consumption $\left(\mathrm{VO}_{2}\right)$ and ammonia excretion ( $\left(\dot{V} \mathrm{NH}_{4}^{+}\right)$rates] and body composition (e.g. carbon and nitrogen) of Monoporeia affinis (Lehtonen 1996a, b) were used to calculate the assimilation (production + metabolism) by the amphipod population. The results and detailed descriptions of the methods used can be found in the papers above. Production of the amphipod population (Table 4) was calculated using seasonal carbon and nitrogen values measured for different age classes and combining them with population data.

Mineralization by the amphipod population. The amphipods collected on each sampling date were grouped into $0.5 \mathrm{~mm}$ length classes. Mean DWs from each length class were fitted into the allometric model $E=\mathrm{a} W^{\mathrm{b}}$, where $E=$ excretion rate $\left(\mu \mathrm{mol} \mathrm{NH_{4 } ^ { + }} \mathrm{d}^{-1}\right)$, $W=$ mean dry wt $(\mathrm{mg})$ of the individuals from a given

Table 3. Monoporeia affinis. A comparison of different methods commonly used in weight determinations. Samples were taken on 7 January 1991 at the study station SR5. Formalin-preserved amphipods were stored for 3 mo in $5 \%$ hexamin-buffered formalin solution. $n$ : number of weighed groups $\times$ number of individuals in each group

\begin{tabular}{|c|c|c|c|c|c|c|}
\hline & \multirow[t]{2}{*}{$\mathrm{n}$} & \multicolumn{3}{|c|}{ Fresh } & \multicolumn{2}{|c|}{ Formalin-preserved } \\
\hline & & Wet & Oven-dried & Lyophilized & Wet & Oven-dried \\
\hline \multicolumn{7}{|c|}{ Weight (mg) per individual } \\
\hline$\sim 1$ yr olds & $3 \times 10$ & 1.61 & 0.41 & 0.38 & 1.39 & 0.22 \\
\hline-2 yr olds & $3 \times 5$ & 5.07 & 1.51 & 1.39 & 4.79 & 0.90 \\
\hline Gravid females & $3 \times 5$ & 18.66 & 4.00 & 4.25 & 17.70 & 2.89 \\
\hline \multicolumn{7}{|c|}{ Water $(\%)$ of fresh weight } \\
\hline$\sim 1$ yr olds & $3 \times 10$ & 74.8 & 76.4 & 86.2 & & \\
\hline-2 yr olds & $3 \times 5$ & 70.3 & 72.6 & 82.2 & & \\
\hline \multirow[t]{2}{*}{ Gravid females } & $3 \times 5$ & 78.6 & 77.2 & 84.5 & & \\
\hline & \multicolumn{2}{|c|}{$\begin{array}{l}\text { Lyophilized wt vs } \\
\text { formalin oven-dried wt }\end{array}$} & \multicolumn{2}{|c|}{$\begin{array}{l}\text { Formalin wet wt vs } \\
\text { formalin oven-dried wt }\end{array}$} & \multicolumn{2}{|c|}{$\begin{array}{c}\text { Formalin wet wt vs } \\
\text { lyophilized wt }\end{array}$} \\
\hline$\sim 1$ yr olds & \multicolumn{2}{|c|}{1.73} & \multicolumn{2}{|r|}{6.32} & \multicolumn{2}{|r|}{3.66} \\
\hline-2 yr olds & \multicolumn{2}{|c|}{1.54} & \multicolumn{2}{|r|}{5.32} & \multicolumn{2}{|r|}{3.45} \\
\hline Gravid females & \multicolumn{2}{|c|}{1.47} & \multicolumn{2}{|r|}{6.12} & \multicolumn{2}{|r|}{4.16} \\
\hline Mean & \multicolumn{2}{|c|}{1.58} & \multicolumn{2}{|r|}{5.92} & \multicolumn{2}{|r|}{3.76} \\
\hline
\end{tabular}


Table 4. Primary production and sedimentation of carbon (C) and nitrogen $(N)$ in relation to production (periods of positive growth) and metabolic requirements of Monoporeia affinis. Quasi-annual and active period (15 April to 14 July) totals have been chosen. Nitrogen produced in primary production was obtained using a C:N ratio of 7 . PP: primary production, Sed: sedimenta-

tion; $P$ : production: $R$ : respiration; E: nitrogen excretion. Please note discussion on the applicability of sedimentation data

\begin{tabular}{|c|c|c|c|c|c|c|c|c|c|}
\hline \multirow{2}{*}{$\begin{array}{l}\text { Carbon } \\
\text { Period } \\
\text { Quasi-annual }\end{array}$} & \multirow[t]{2}{*}{$\begin{array}{c}\mathrm{PP} \\
\left(\mathrm{g} \subset \mathrm{m}^{-2}\right.\end{array}$} & \multirow[t]{2}{*}{$\begin{array}{l}\text { Sed } \\
\left.\text { riod }^{-1}\right)\end{array}$} & \multirow[t]{2}{*}{$\begin{array}{l}\text { Sed:PP } \\
(\%)\end{array}$} & & \multicolumn{2}{|c|}{$\begin{array}{c}\text { Monoporeia affinis } \\
R \quad p+R \\
C^{-2} \text { period }^{-1} \text { ) }\end{array}$} & \multirow[t]{2}{*}{$\begin{array}{l}P: R \\
\text { ratio }\end{array}$} & \multicolumn{2}{|c|}{$\begin{array}{c}(P+R): \mathrm{PP} \quad(P+R): \text { Sed } \\
(\%)\end{array}$} \\
\hline & & & & & & & & & \\
\hline $199115 \mathrm{Feb}-14$ Nov & 104.8 & 18.4 & 17.5 & 5.75 & 12.56 & 18.31 & 0.46 & 17.5 & 99.7 \\
\hline $199215 \mathrm{Mar}-14 \mathrm{Sep}$ & - & - & - & 2.72 & 6.37 & 9.09 & 0.43 & - & - \\
\hline $199315 \mathrm{Mar}-14 \mathrm{Jul}$ & - & 9.2 & - & 1.51 & 3.14 & 4.65 & 0.48 & - & 50.6 \\
\hline \multicolumn{10}{|l|}{ Active period } \\
\hline $199115 \mathrm{Apr}-14 \mathrm{Jul}$ & 72.6 & 13.9 & 19.2 & 4.07 & 3.31 & 7.38 & 1.23 & 10.2 & 53.1 \\
\hline 199215 Apr-14 Jul & - & - & - & 1.39 & 3.01 & 4.40 & 0.46 & - & - \\
\hline $199315 \mathrm{Apr}-14 \mathrm{JuI}$ & - & 8.1 & - & 1.44 & 2.48 & 3.92 & 0.58 & - & 48.6 \\
\hline \multirow{2}{*}{$\begin{array}{l}\text { Nitrogen } \\
\text { Period }\end{array}$} & PP & Sed & Sed:PP & & Monopo & a affinis & & $(P+E): P$ & $(P+E)$ :Sed \\
\hline & \multicolumn{2}{|c|}{ ( $g \mathrm{~N} \mathrm{~m}^{-2}$ period $\left.^{-1}\right)$} & $(\%)$ & \multicolumn{3}{|c|}{$\left(g \mathrm{~N} \mathrm{~m}^{-2}\right.$ period $\left.^{-1}\right)$} & $\begin{array}{l}P: E \\
\text { ratio }\end{array}$ & \multicolumn{2}{|c|}{$(\%)$} \\
\hline \multicolumn{10}{|l|}{ Quasi-annual } \\
\hline $199215 \mathrm{Mar}-14$ Sep & - & ${ }_{-}^{1.9}$ & - & 0.30 & 0.15 & 0.45 & 2.00 & - & $\begin{array}{l}40.0 \\
-\end{array}$ \\
\hline $199315 \mathrm{Mar}-14 \mathrm{Jul}$ & - & 0.9 & - & 0.15 & 0.12 & 0.27 & 1.25 & - & 31.2 \\
\hline \multicolumn{10}{|l|}{ Active period } \\
\hline $199115 \mathrm{Apr}-14 \mathrm{Jul}$ & 10.4 & 1.3 & 12.6 & 0.34 & 0.13 & 0.47 & 2.61 & 4.5 & 36.1 \\
\hline $199215 \mathrm{Apr}-14 \mathrm{Jul}$ & - & - & - & 0.13 & 0.08 & 0.21 & 1.62 & - & - \\
\hline $199315 \mathrm{Apr}-14 \mathrm{Jul}$ & - & 0.8 & - & 0.14 & 0.10 & 0.24 & 1.40 & - & 31.2 \\
\hline
\end{tabular}

length class, $b=$ non-empirical exponent 0.75 (Peters 1983) and $\alpha=$ intercept, calculated for each sampling date separately. Excretion rates were temperaturecorrected using a temperature coefficient $\left(Q_{10}\right)$ of 2.67 for $\mathrm{VNH}_{4}^{+}$(Lehtonen unpubl.). The $\dot{V} \mathrm{O}_{2}$ was estimated in a similar way, using equations $R\left(\mu \mathrm{l} \mathrm{O}_{2} \mathrm{~d}^{-1}\right)=$ $14.29 W(\mathrm{mg} \text { dry } w \mathrm{t})^{0770}$ (October to April period), $R=18.32 W^{0.774}$ (May to September period) and $R=13.93 W^{1.030}$ (gravid females), where $R=$ respiration rate (Lehtonen $1996 \mathrm{~b}$ ). An empirical $Q_{10}$ value of 1.70 for $\mathrm{VO}_{2}$ (Lehtonen unpubl.) was used. Since amphipods use mostly lipids for metabolism, a respiratory quotient $(R Q)$ of 0.75 was chosen to convert $\dot{V O}_{2}$ to carbon (C) units. Both excretion and respiration values were multiplied by the number of individuals in each length class, and the instantaneous metabolism of the whole population was calculated by summing up the values of all length classes; the results were integrated for the whole study period (see below).

Primary production and sedimentation. Data on seasonal measurements of primary production at the study station in 1991 were obtained from. Andersson et al. (1996). Settling particles were collected in 1991 (14 February to 17 November) and 1993 ( 7 March to 28 July) by an automated funnel-shaped multisample trap ('Kiel Type', Germany; opening diameter $80 \mathrm{~cm}$; see Zeitzschel et al. 1978), moored at the sampling station SR5 at a depth of $80 \mathrm{~m}$. The trap was equipped with revolving sample bottles that allowed a frequent sampling ( 2 to $3 \mathrm{~d}$ interval during the spring bloom, $3 \mathrm{~d}$ at other times). Prior to sampling, the sample bottles were filled with $4 \%$ formalin prepared in 8 PSU seawater. After lyophilization of the collected material, total DW, carbon and nitrogen (Heraeus CHN analyzer), as well as phosphorus, silica and chlorophyll a were determined from the dry matter [essentially as described in Leppänen (1988)]. Inorganic salts are not completely removed by this procedure; in the present paper, however, $\mathrm{C}+\mathrm{N}+\mathrm{P}$ is considered to represent roughly the organic fraction of the sample. In 1993, only DW, carbon and nitrogen were measured.

Interpolation of the results over time periods. The results from amphipod DW, carbon and nitrogen production, respiration and excretion, as well as sedimentation and the original data on primary production (Andersson et al. 1996), were interpolated linearly between sampling dates over the whole study period. Periodical totals were obtained from the daily rates; for convenience, the periods used here were chosen to be monthly and extended from the 15 th day of month A to the 14 th day of month $B$. 


\section{RESULTS}

\section{Near-bottom hydrography}

Seasonal variations in the near-bottom hydrographical conditions are presented in Fig. 1. The temperature varied between 2.1 and $5.4^{\circ} \mathrm{C}$, with the highest values in late autumn and the lowest in early summer. The oxygen content varied between 5.0 and $7.9 \mathrm{mg} \mathrm{O}_{2} \mathrm{l}^{-1}$ and showed a weak negative correlation with temperature. No marked seasonal variation was observed in the salinity.

\section{Primary production and sedimentation}

The data by Andersson et al. (1996) showed that in 1991 the intensive period of primary production occurred in April/May, with a peak in mid-May. Between June and September the production rates were markedly lower and negligible between late autumn to early spring. The peak of sedimentation occurred after about a 2 wk time lag, with maximum rates in late May/early June and a marked reduction in rates from mid-June onwards (Fig. 2, Table 4). Relating primary production to the amount of material collected by the trap, from the 'quasi-annual' (15 February to 14 November) production of $105 \mathrm{~g} \mathrm{C} \mathrm{m}^{-2}$, only an amount corresponding to $17.5 \%\left(18.4 \mathrm{~g} \mathrm{C} \mathrm{m}^{-2}\right)$ was found in the trap. From the material produced during the most productive period (15 April to 14 June), $73 \mathrm{~g} \mathrm{C} \mathrm{m}^{-2}$, a sedimentation of $19.2 \%$ was calculated. The amount of sedimenting carbon was markedly lower in 1993; a total of $8.1 \mathrm{~g} \mathrm{C} \mathrm{m}^{-2}$ sedimented between 15 April and 14 July 1993, compared to the $13.9 \mathrm{~g} \mathrm{C} \mathrm{m}^{-2}$ that accumulated during the same period in 1991 (Table 4). In most other respects, the seasonal sedimentation patterns and chemical characteristics of the sedimenting matter were similar in 1993 and 1991 and are not presented here.
The quality of the sedimenting material varied markedly during the year (Fig. 2). A rough index for the quality of the sedimenting matter, obtained by calculating the ratio $(\mathrm{C}+\mathrm{N}+\mathrm{P})$ : [total $\mathrm{DW}-(\mathrm{C}+\mathrm{N}+\mathrm{P})]$, indicated that the inorganic portion of the material caught by the trap was high (60 to 95\%). During the period of intense phytoplankton production, the organic fraction of sedimenting matter was markedly greater than at other times. Strongly varying $C: N, C: P$ and N:P ratios, as well as the chlorophyll a content and C:chlorophyll a ratio, showed seasonal variability in the quality of the material. All the calculated ratios suggested that a great deal of the material reaching the $80 \mathrm{~m}$ trap was not coming directly from the euphotic layer, but was resuspended or laterally transported to the area. This was found to be more accentuated in the late summer when very high $C: N$ ratios (even $>70$ ) were recorded for a period lasting about 1 mo. The C:P and N:P ratios approximately tripled their basic levels during the late spring and remained high until late autumn, during which time the C:chlorophyll a ratio was also elevated. However, since ca $90 \%$ of the sedimentation occurred between 7 May and 16 June, in terms of nutrition, the variation in the quality of the deposited material outside this period is likely to be of small importance to the amphipods.

\section{The macrobenthic community}

Only 4 infaunal species, the polychaete Harmothoë sarsi and the crustaceans Saduria entomon, Pontoporeia femorata and Monoporeia affinis formed the macrobenthic community at the study location. $M$. affinis contributed 94 to $99 \%$ of the density and 45 to $99 \%$ of the biomass (formalin wet weight); at 13 out of 16 sampling occasions $M$. affinis formed more than $70 \%$ of total biomass. The occasionally low $M$. affinis biomass dominance values were caused by the presence of a single large specimen of $S$. entomon.
Fig. 1. Hydrographic conditions in the near-bottom water at the study station during the study period 1991 to 1993

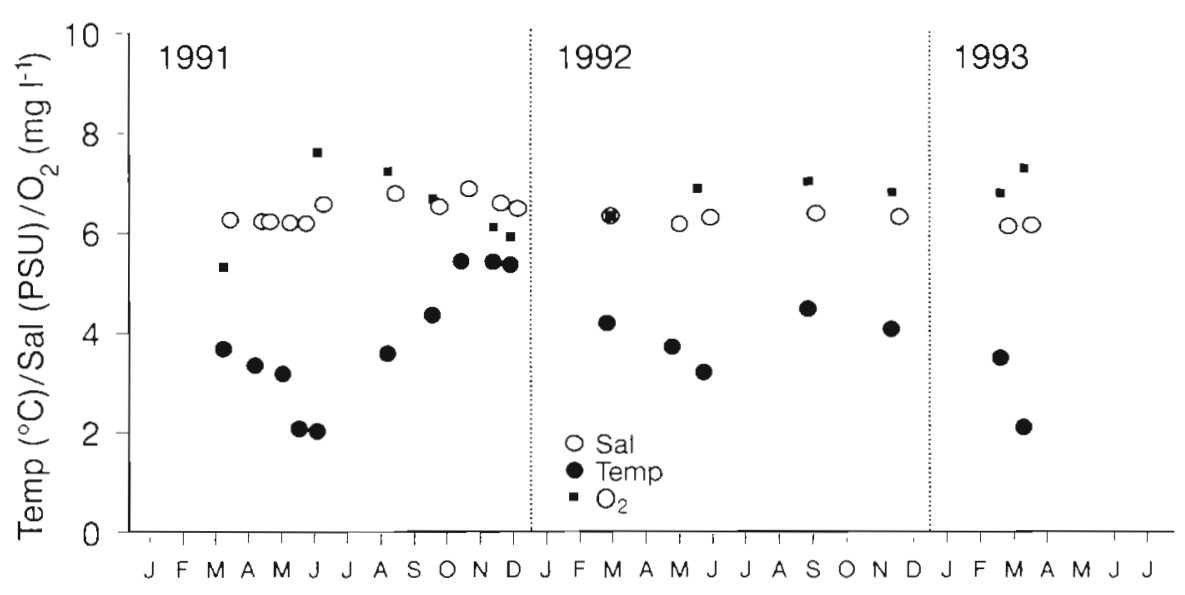



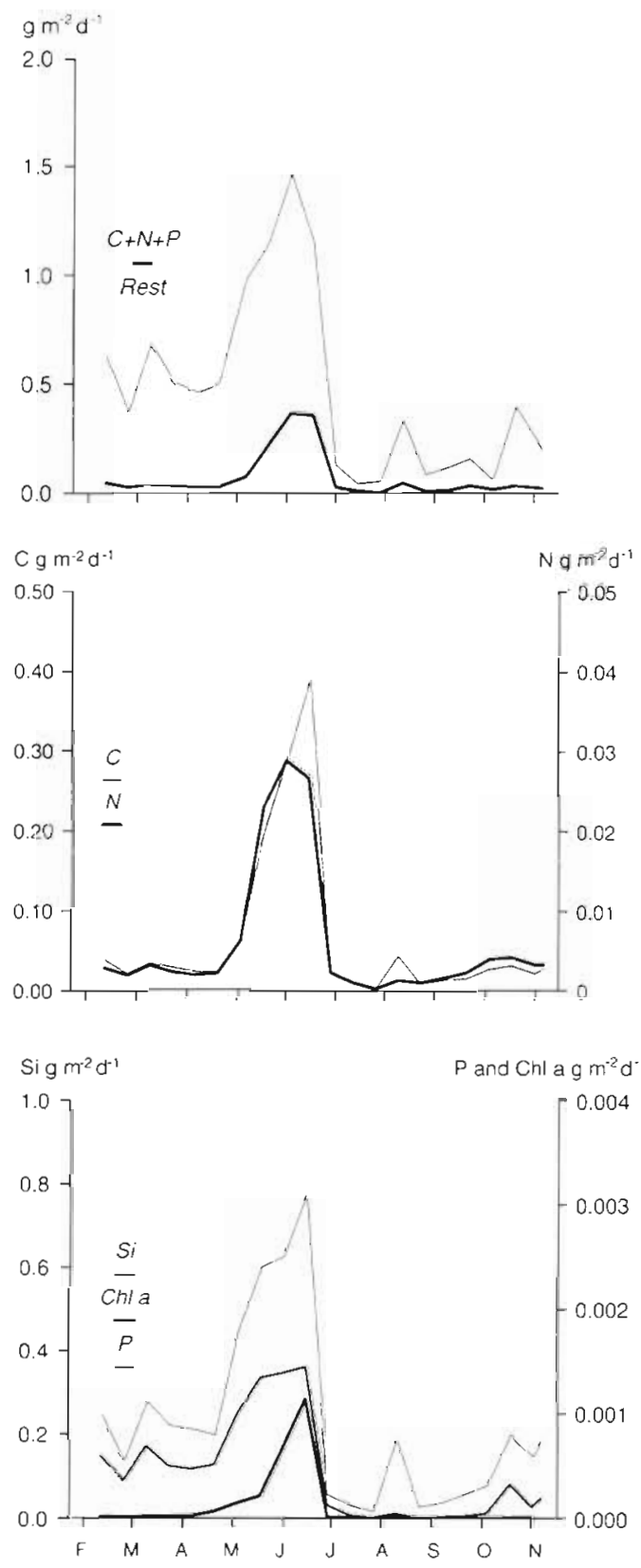

\section{Monoporeia affinis population dynamics}

Total biomass and abundance

The biomass and density of the Monoporela affinis population varied markedly during the year, and also interannually. Highest biomass ( $\mathrm{g} \mathrm{DW} \mathrm{m}^{-2}$ ) always occurred in late summer/autumn [1991: 13.41; 1992: 9.87; 1993: 9.56], and the lowest in spring (1991 3.29i 1992: 3.70, 1993: 4.86) (Fig. 3a). A decline in maximum density values (ind. $\mathrm{m}^{-2}$ ) during the study years was evident; in June 1991 the density was 9572; in late May 1992 it was 7700 and in late May 1993 only 4675
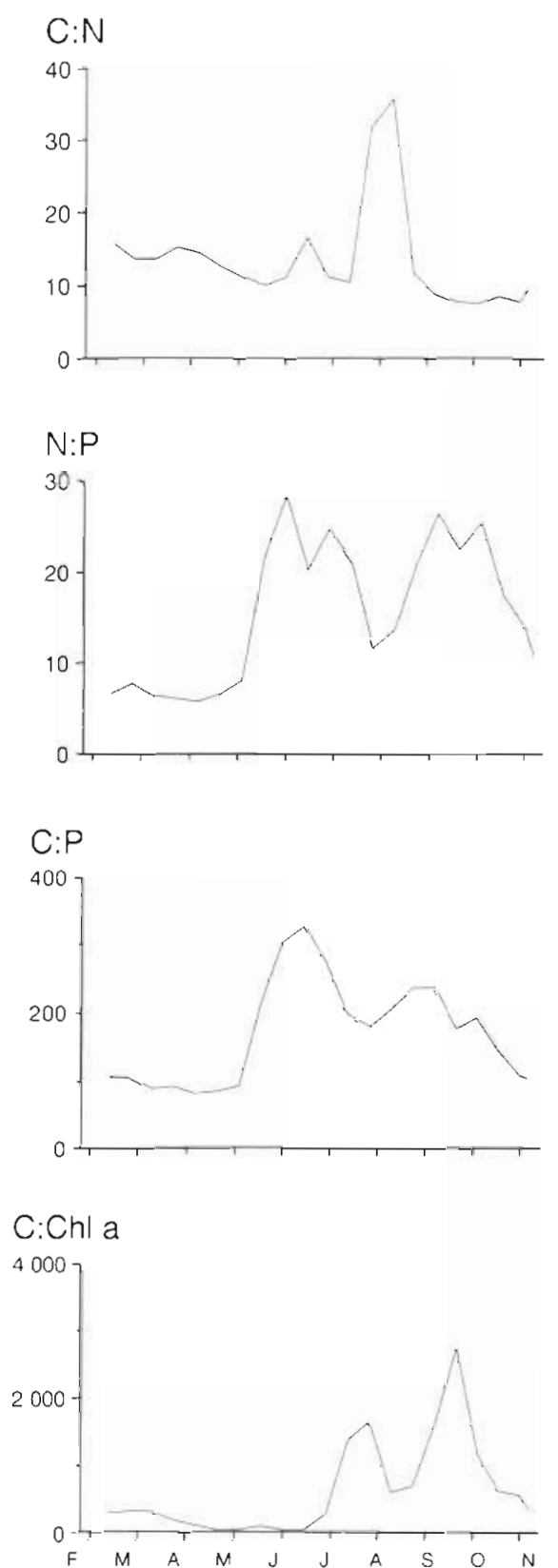

Fig. 2. Sedimentation characteristics at the study station during 1991. The sedimentation trap was moored at a depth of $80 \mathrm{~m}$. automatic sampling occurred at 3 d intervals

(Fig. 3b). Note should be taken that the maximum densities given for the spring are severe underestimates, since the $0+$ yr olds were not sampled quantitatively during the first 2 to 3 mo after their release (see below).

\section{Cohort dynamics}

During the study period, 3 distinct year classes in the Monoporeia affinis population were found each year. The males die soon after copulation in late autumn, and the females after releasing the young in March/ April. The amphipods matured during their third 

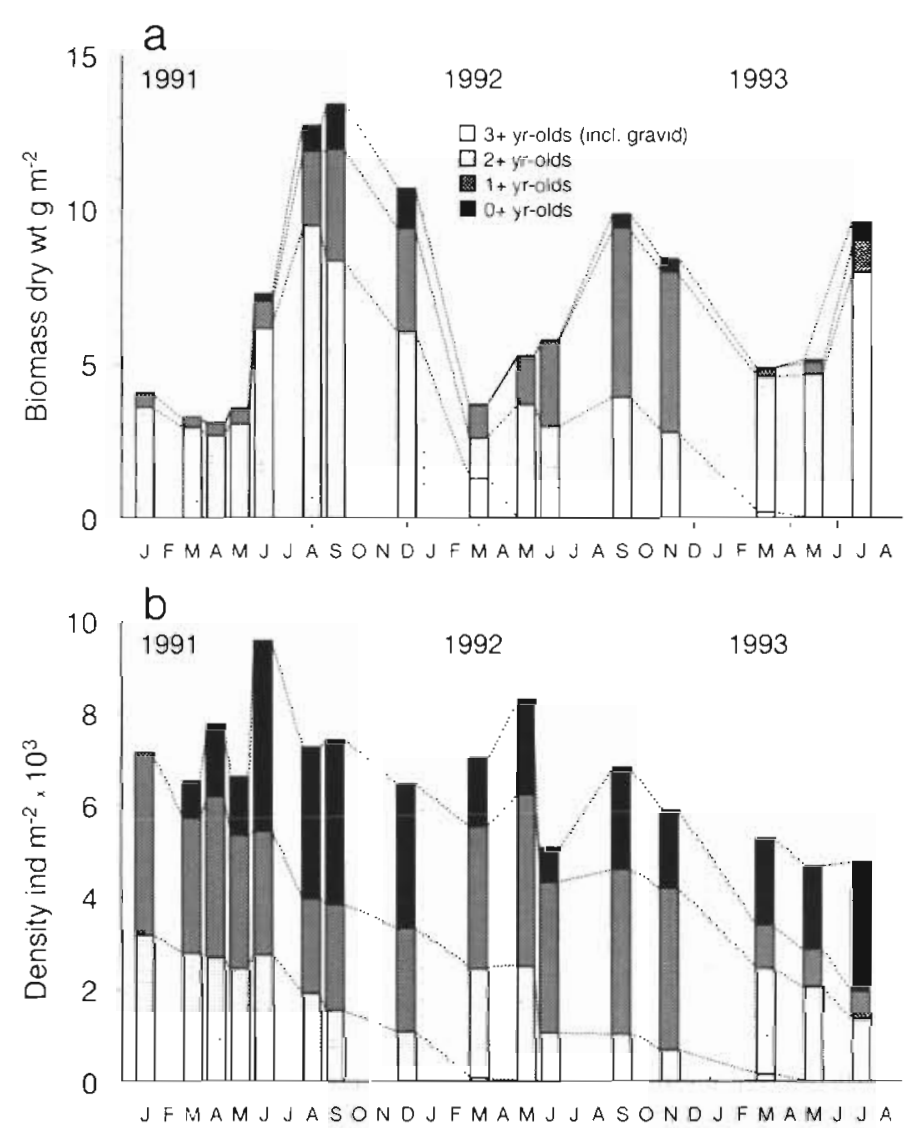

Fig. 3. Monoporeia affinis. Seasonal changes in (a) biomass and (b) density of the study population during the study period 1991 to 1993

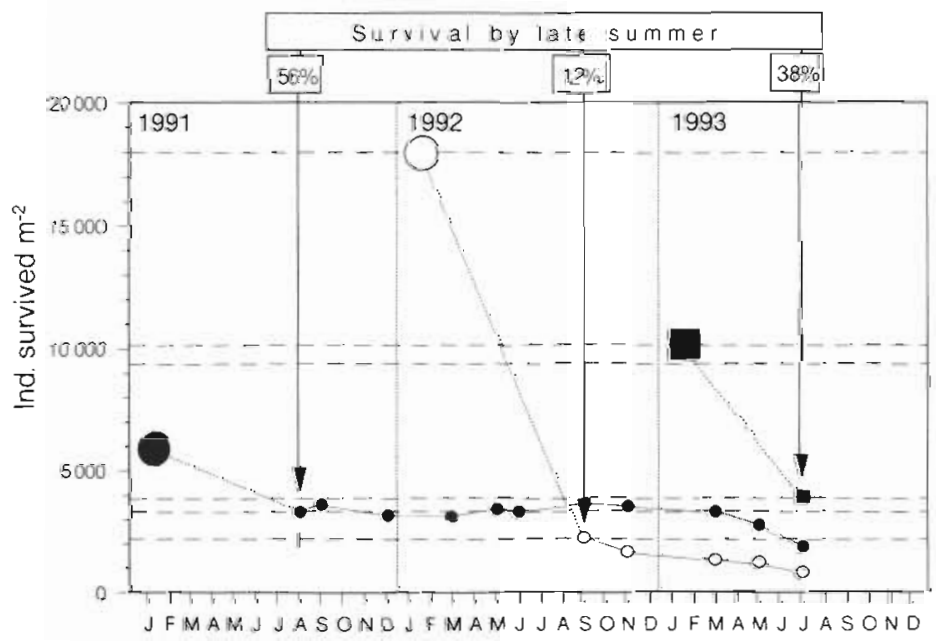

Fig. 4. Monoporeia affinis. Reproductive success of annual cohorts during different study years, examined by estimating the potential offspring output (= number of gravid females found in winter/early spring multiplied by the number of eggs per female in a given length class; large symbols) and the observed number of survivors of the cohort collected from late summer onwards autumn, when between September to December males as well as egg-bearing females were registered in the samples. Due to the uncertainties in the effectiveness of the sampling technique in capturing the newborn in March/April (partly blown away from the sediment surface by even a minor pressure wave caused by the landing of the grab), offspring survival (as a \% of the estimated reproductive output) could only be followed by examining the dynamics of the $0+y r$ olds from June onwards.

The reproductive success and, consequently, the size of the cohorts varied markedly between the years (Fig. 4). The theoretical number of offspring was clearly highest in 1992 because both the average number and size of the females were greater than in 1991 and 1993, greater size also having a positive effect on fecundity (Fig. 5). Mortality in this cohort was, however, dramatically higher compared to those born in 1991 and 1993; furthermore, in this cohort, the number of the remaining individuals continued to decrease markedly (Fig. 4)
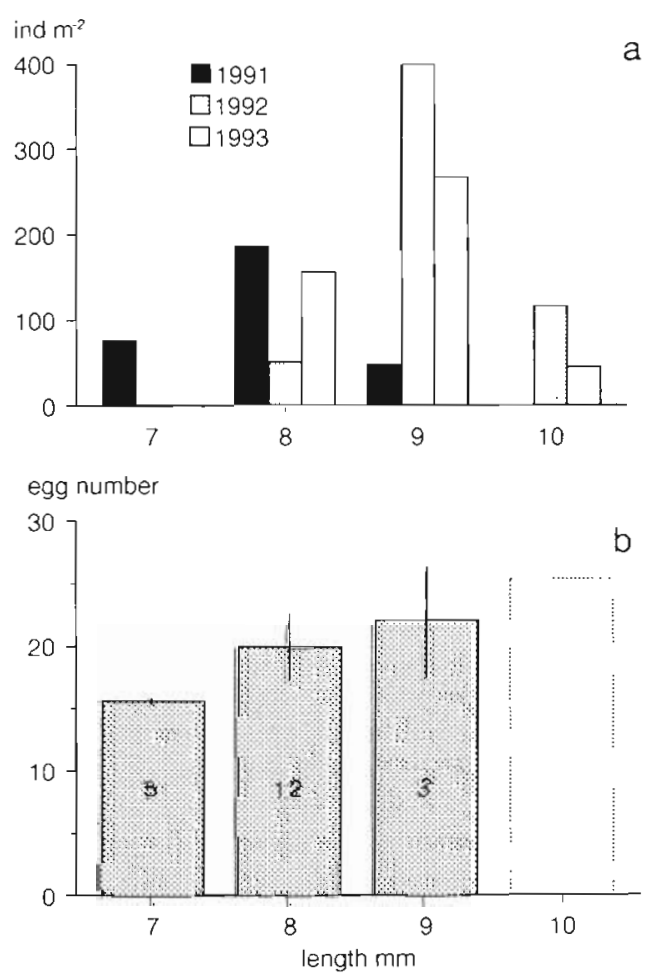

Fig. 5. Monoporeia affinis. (a) Size-frequency distribution of gravid females during the study period 1991 to 1993. (b) Relationship between the length of gravid females (number of measured individuals shown inside the bars) and the number of eggs per female, obtained from the sample collected in November 1990; the number of eggs in the $10 \mathrm{~mm}$ size class was obtained by regression 


\section{Growth of the individuals}

The growth (DW and body length) of Monoporeia affinis representing different annual cohorts followed a distinct pattern from year to year, with 2 very characteristic features: (1) a long period of no growth (or even negative growth) from late autumn to late spring; and (2) a very sharp, seemingly exponential rise in growth in early summer (Fig. 6). In 1991, growth continued until early autumn and was then completely halted until the next spring. In 1992, weight increment of the amphipods had ceased already by late summer.

To describe changes in the condition of the amphipods, a fatness index (FI), relating body DW to body length, was determined. The index was calculated as $F I=D W(m g): 0.00227 \times$ length $(\mathrm{mm})^{3.30}$, where the mean weight and length of the individuals representing the annual cohort at each sampling were fitted into the equation obtained by using combined data for the whole study period ( $n=310, r^{2}=0.97$ ). The FI showed seasonal variation coinciding with the accumulation and depletion of lipid reserves (Lehtonen 1996a) (Fig. 7). More important, interannual differences in the condition of the individuals representing different annual cohorts were clearly shown by this index; the reduced biomass increment during 1992 was especially marked.

\section{Production, metabolic requirements and mineralization potential of the population}

In order to compare the different study years, values for primary production, sedimentation, as well as production and metabolism of the Monoporeia affinis population were calculated for the 'active period', i.e. the time when all these rates are at their highest.

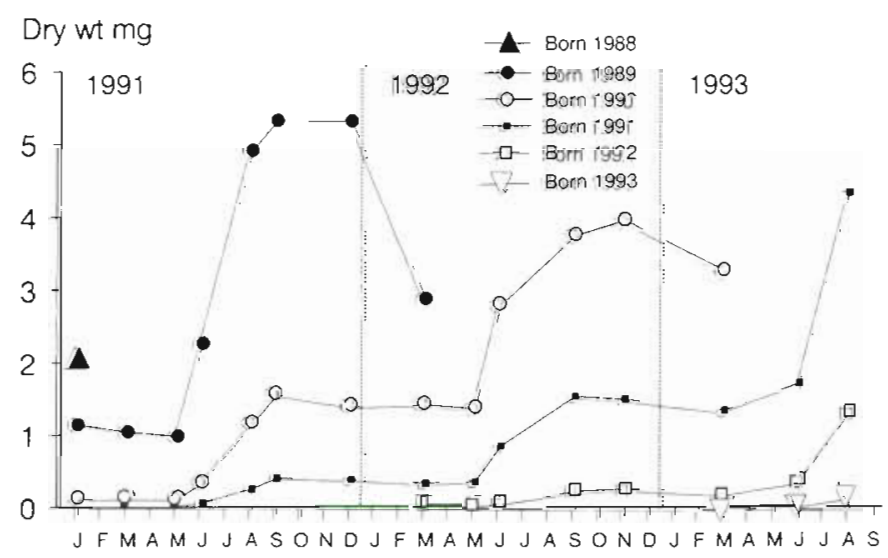

Fig. 6. Monoporeia affinis. Seasonal changes in the mean dry weight of individuals representing different annual cohorts during the study period 1991 to 1993
Because sampling was terminated on 28 July 1993, the period between 15 April and 14 July was chosen since it covers both the start and the end of major primary production and sedimentation, and allowed a time lag for the utilization of settled organic matter by the amphipod population.

In 1991, the Monoporeia affinis population assimilated [production $(P)+$ respiration $(R)] 17.5 \%$ of the 'quasi-annually' (15 February to 14 November) produced carbon (Table 4), while a proportion of $10.2 \%$
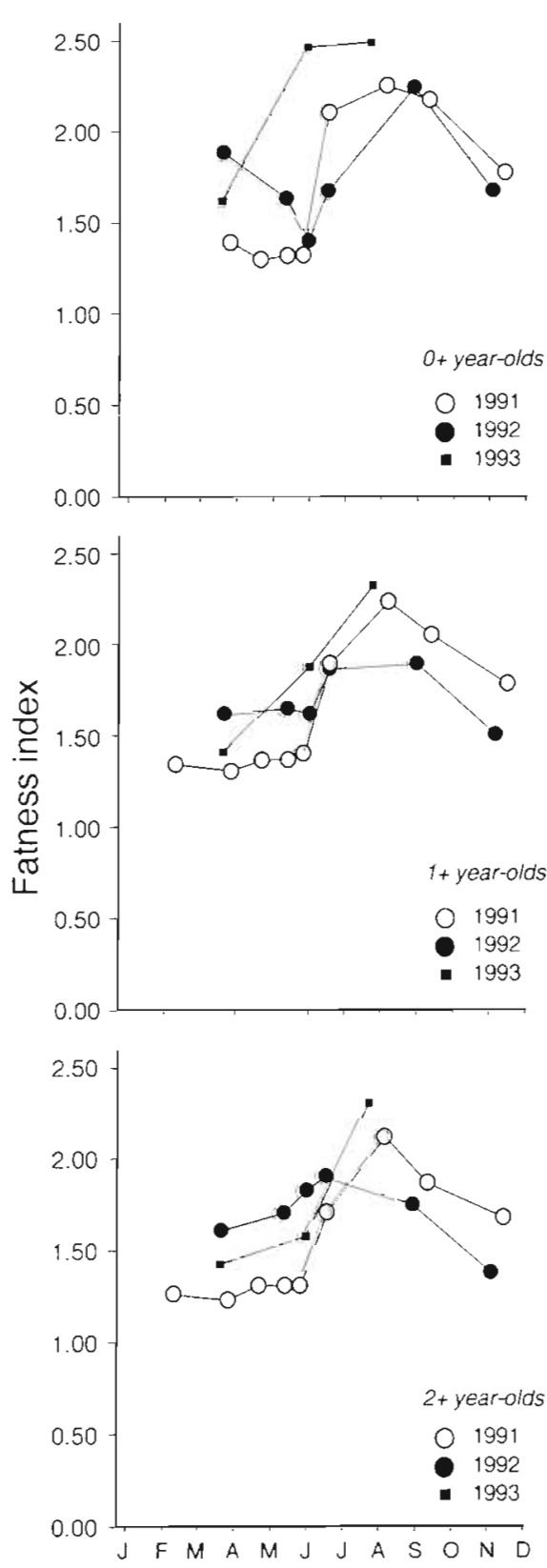

Fig. 7. Monoporeia affinis. Seasonal changes in the fatness index (FI) of individuals representing different annual cohorts during the study period 1991 to 1993 
was calculated for the active period. Utilization of nitrogen $[P+$ excretion $(E)]$ accounted for $5.7 \%$ (quasi-annual) and $4.5 \%$ (active period). An unrealistically high proportion (99.7\%) of the quasiannual sedimentation of carbon was calculated to be utilized by the amphipods. In $1991,53 \%$ of the sedimented carbon was assimilated by the amphipods during the active period, the proportion being very similar $(49 \%)$ in 1993 . The $P: R$ ratio during the active period was markedly higher in 1991 (1.23) compared to 1992 (0.46) and 1993 (0.58), showing a substantial allocation to growth in 1991. The $P: E$ ratio, reflecting nitrogen dynamics in the amphipods, showed interannual variations similar to those of the $P: R$ ratio

The daily respiration rate of the Monoporeia affinis population ranged between 18.8 and $72.2 \mathrm{mg} \mathrm{C} \mathrm{m}^{-2} \mathrm{~d}^{-1}$ (Table 5). Total monthly respiration was higher between July and January (1.13 to $2.03 \mathrm{~g} \mathrm{C} \mathrm{m}^{-2}$ period $^{-1}$ ) than between February and June $\left(0.58\right.$ to $1.54 \mathrm{~g} \mathrm{C} \mathrm{m} \mathrm{m}^{-2}$ period $^{-1}$ ) (Fig. 8a). Annual carbon mineralization rates were $17.1 \mathrm{~g} \mathrm{C} \mathrm{m}^{-2} \mathrm{yr}^{-1}$ (January 1991 to January 1992) and $14.4 \mathrm{~g} \mathrm{C} \mathrm{m}^{-2} \mathrm{yr}^{-1}$ (January 1992 to January 1993). The rates of release showed marked seasonal variability, ranging from 8.6 to $179.1 \mu \mathrm{mol}$ (0.1 to $2.5 \mathrm{mg}) \mathrm{m}^{-2} \mathrm{~d}^{-1}$ (Table 5). Subsequently, monthly excretion values varied greatly, being higher in summer (June to August: 37 to $70 \mathrm{mg} \mathrm{m}^{-2}$ period ${ }^{-1}$ ) than at other times ( 8 to $49 \mathrm{mg} \mathrm{NH}{ }_{4}^{+} \mathrm{m}^{-2}$ period ${ }^{-1}$ ) (Fig. $8 b$ ). The annual release by this $M$. affinis population was $31.0 \mathrm{mmol}$ (433 $\mathrm{mg}$ ) $\mathrm{m}^{-2} \mathrm{yr}^{-1}$ (January 1991 to January 1992) and $15.2 \mathrm{mmol}(213 \mathrm{mg}) \mathrm{NH}_{4}^{+} \mathrm{m}^{-2} \mathrm{yr}^{-1}$ (January 1992 to January 1993).
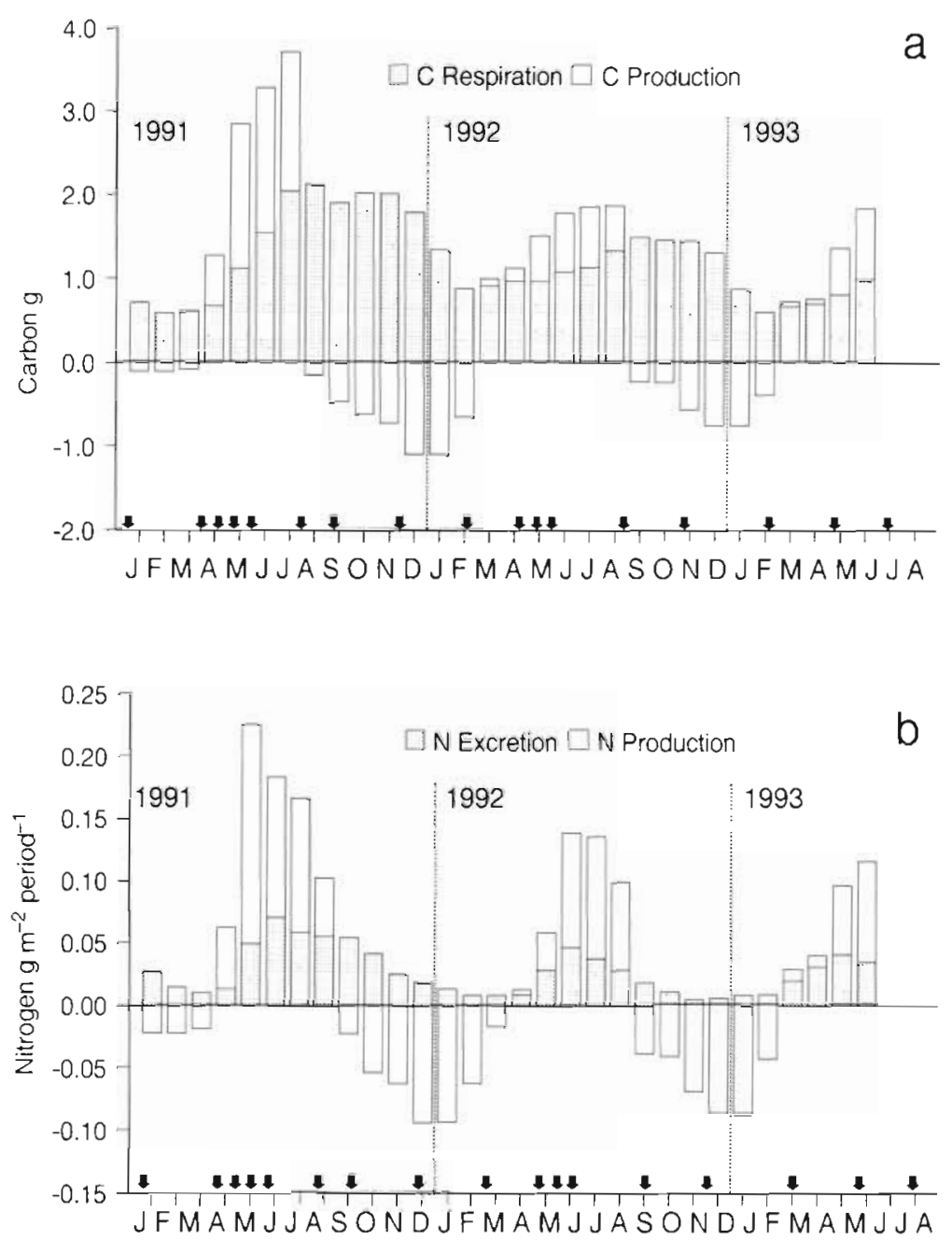

Fig. 8. Monoporeia affinis. Assimilation of (a) carbon and (b) nitrogen by the population $\left(\mathrm{g} \mathrm{m}^{-2}\right.$ period $\left.{ }^{-1}\right)$, divided into monthly net secondary production and metabolic requirements. After interpolation of the original data over the whole sampling period (17 January 1991-28 July 1993), the data were reconstituted to monthly intervals. The negative production values indicate loss of biomass. Arrows = actual sampling dates
Table 5. Monoporeia affinis. Mineralization potential of the amphipod population studied. $R_{\mathrm{mmn}}$ and $R_{\mathrm{md} .}$. minimum and maximum daily mineralization rates during the year

\begin{tabular}{|c|c|c|c|c|c|c|}
\hline & \multicolumn{3}{|c|}{ Carbon } & \multicolumn{3}{|c|}{ Nitrogen } \\
\hline & \multicolumn{2}{|c|}{$\begin{array}{l}\text { Daily rate } \\
\left(\mathrm{mg} \mathrm{C} \mathrm{m}^{-2}\right)\end{array}$} & \multirow[t]{2}{*}{$\begin{array}{l}\text { Annual total } \\
\left(\mathrm{g} \mathrm{C} \mathrm{m}^{-2}\right)\end{array}$} & \multicolumn{2}{|c|}{ 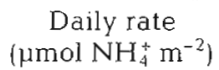 } & \multirow[t]{2}{*}{$\begin{array}{c}\text { Annual total } \\
\left(\mathrm{mmol} \mathrm{NH} \mathrm{m}^{+} \mathrm{m}^{-2}\right)\end{array}$} \\
\hline & $R_{\mathrm{m} 1 \mathrm{n}}$ & $R_{\max }$ & & $R_{\min }$ & $R_{\max }$ & \\
\hline $1991^{a}$ & 18.8 & 72.2 & 17.1 & 22.6 & 179.1 & 31.0 \\
\hline $1992^{\mathrm{a}}$ & 27.1 & 50.1 & 14.4 & 8.6 & 121.8 & 15.2 \\
\hline $1993^{b}$ & 19.7 & 39.9 & - & 14.2 & 96.0 & - \\
\hline
\end{tabular}

\section{DISCUSSION}

The striking effect of the sedimentation of the spring phytoplankton bloom on the growth of the Monoporeia affinis individuals and the equally marked nongrowth period during the winter are exquisitely illustrated in this study. In coastal areas, the post-bloom period has also been established as the main period of growth for these amphipods (Cederwall 1977, Sarvala 1986, Uitto \& Sarvala 1991). In the present study, the continuation of growth until early autumn despite an 
extensive reduction in primary production and, more important, in sedimentation rates during the summer indicates that benthic nutritional conditions remain favourable for growth also during the summer (see below). Interannual differences were, however, marked Furthermore, the growth dynamics of this amphipod population reflected the observed seasonal variations in their metabolism and body composition (Lehtonen $1996 \mathrm{a}, \mathrm{b})$

The extensive autumn/early spring period of low quantity and quality food input, combined with a constantly low temperature, has produced a strategy for high energy storage and reduced metabolic rate in the amphipods (Lehtonen 1996a, b), the latter probably inducing the observed 3 yr life-cycle. The longevity of Monoporeia affinis and its North American relative Diporeia spp. has been associated with depth and temperature (Segerstråle 1937, Moore 1979, Leonardsson et al. 1988), and aIso with trophic conditions (Siegfried 1985j. On shallow coastal soft-bottoms, where strong seasonal oscillations in temperature have a considerable effect on metabolic rates, the life-cycle and population dynamics of the amphipods are different to the populations inhabiting deep, open-sea areas, where growth cannot be temperature-regulated because low temperatures prevail throughout the year (Fig. 1). In the study area, it is evident that available food is the key factor regulating the growth, life-cycle and overall population dynamics of the species.

\section{Pelagic processes affecting sedimentation}

During the spring bloom, the downward flux of algae through the water column is likely to be rapid, the particles reaching the bottom in a matter of days (in the Baltic Sea area; see e.g. Smetacek et al. 1978, Smetacek 1985 and citations within, Heiskanen \& Kononen 1994. Heiskanen \& Leppänen 1995). Since the abundance of zooplankton grazers in the northern Baltic Sea is low at the time of the spring bloom (Viitasalo 1994), the organic material produced should reach the benthos in high proportion relative to primary production, being also relatively unprocessed and thus of good nutritional value. In a northern Baltic open-sea area, ciliates and mesozooplankton have been shown to consume only 28 and $7 \%$, respectively of the primary production during the spring bloom period (Leppänen \& Bruun 1988). Interannual variations in the portion of diatoms in the spring bloom assemblage may also affect the quality of the food input during the spring bloom, and lead to variations in the condition of the amphipod populations, as has been demonstrated by Johnson \& Wiederholm (1992) in a study on long-term population fluctuations of Monoporeia affinis in a Swedish lake.
The sedimentation values recorded here are in the same order of magnitude as those recorded in other areas of the Baltic Sea. In the shallow Kiel Bight, Graf et al. (1982) recorded sedimentation of $11.5 \mathrm{~g} \mathrm{C} \mathrm{m}^{-2}$ during the $4 \mathrm{wk}$ period of the spring bloom, while in the Bornholm Basin (southern Baltic Sea), a carbon flux of $6.2 \mathrm{~g} \mathrm{C} \mathrm{m}^{-2}$ in $34 \mathrm{~d}$ during the spring bloom was recorded by Smetacek et al. (1978). In a deep, opensea area study that must be regarded as most relevant to the present one, Leppänen (1988) recorded sedimentation up to $43.7 \mathrm{~g} \mathrm{C} \mathrm{m}^{-2}$ during the spring bloom. However, since differences in the methods of measuring sedimentation often lead to highly variable results (see below), the comparisons are of limited value.

\section{Benthic community response to sedimentation}

The annual total assimilation $(P+R)$ of carbon by the Monoporeia affinis population is comparatively high with regard to the amount of carbon fixed by primary production (17\%; Table 4), but not unusual. Early work by Riley (1956) in Long Island Sound showed utilization by the benthos to be $31 \%$ of primary production. Concerning coupling with sedimentation, Wassmann (1984) calculated the proportion of carbon utilized by the benthic community to be 40 to $47 \%$ of sedimented carbon in a Norwegian fjord. The results obtained here on the annual carbon requirements of the $M$. affinis population (Table 4) are some $25 \%$ higher than those recorded by Uitto \& Sarvala (1991) for a coastal $M$. affinis population $\left(15.2 \mathrm{~g} \mathrm{C} \mathrm{m}^{-2} \mathrm{yr}^{-1}\right)$. In the coastal Askö area (Baltic Sea), Ankar (1977) and Elmgren (1978) estimated the carbon requirements of the benthos (including meiofauna) to be 40 to $60 \mathrm{~g} \mathrm{C} \mathrm{m}^{-2} \mathrm{yr}^{-1}$; if we assume that the $P+R$ of meiofauna in the study area equals that of the amphipods, values indicating the carbon requirements of the benthos recorded in the present study approach the lower end of this estimate.

Apart from macrozoobenthos, meiofauna and bacteria play an important and often predominant role in the utilization of deposited organic matter. A parallel study at the present study station showed an increase in bacterial abundance and biomass immediately after the start of the main period of sedimentation (Mohammadi et al. 1993). With respect to meiofauna, despite a considerably lower biomass compared to macrozoobenthos (in the present area about half of that of the macrofauna; Elmgren 1978), shorter generation times (causing high production/biomass, $P / B$, ratios) and markedly higher weight-specific metabolic rates (cf. common allometric relationship between body size and metabolic rate; e.g. Peters 1983) denote the importance of meiofauna in the cycling of sedimented nutrients. However, in the present study area, the respira- 
tion of Monoporeia affinis comprised about $30 \%$ (seasonal average) of total benthic community respiration (Finnish Institute of Marine Research unpubl. data); combined with the allocation of carbon to growth (Fig. 8a), it is apparent that a large portion of the sedimented organic matter in this location is consumed by the amphipods. Thus, it is claimed that even if the actual deposition rates were, say, 2 to 3 times higher than recorded here, the carbon (and nitrogen) requirements of the amphipod population suggest that it is strongly limited by food, considering the requirements of other members of the benthic community (discussed below).

\section{Quantifying sedimentation: uncertain factors}

Seasonal primary production and the measured sedimentation of particulate carbon barely supported the benthic system in the study area. The annual carbon and nitrogen requirements of the Monoporeia affinis population (Fig. 8, Table 4) are greater than the amount that would be available to them from local primary production after taking into account the requirements of other consumers in the pelagic and benthic food webs. Therefore, the amount of organic matter caught by the sedimentation trap at $80 \mathrm{~m}$ definitely underestimates the total flux at this site. Calculations based on primary production and sedimentation rates can yield highly dubious results in areas where resuspension, lateral transport (discussed in Smetacek et al. 1978, Leppänen 1988) and extensive focusing of material towards the sedimentation basin occur. For example, in the Kiel Bight only $25 \%$ of benthic activity could be attributed to vertical input of organic carbon, pointing out the importance of other transport processes (Graf et al. 1982). The seabed type of the Bothnian Sea is mostly erosion and transport, but this is not the case in the present study area (e.g. Brydsten 1993). The benthos in this area is probably fueled by the concentration of particles from a very much greater pelagial area.

The sedimentation rates of both carbon and nitrogen recorded in the present study are only about half (1991) and one-third (1993) of those recorded by Leppänen (1988) in an open-sea area of the northern Baltic Proper. The study in question showed that resuspension below the halocline distorts the carbon flux measurements during the bloom period ( 3 traps between 30 and $80 \mathrm{~m}: 21.6$ to $22.5 \mathrm{~g} \mathrm{C} \mathrm{m}^{-2}$; traps at 100 and $150 \mathrm{~m}: 43.7$ and $29.6 \mathrm{~g} \mathrm{C} \mathrm{m}^{-2}$ ), while the amount of sedimenting nitrogen varied less (5 trap depths between 30 and $150 \mathrm{~m}: 2.6$ to $3.0 \mathrm{~g} \mathrm{~N} \mathrm{~m}^{-2}$ ). This indicates that the material 'contaminating' the deeper traps was extensively 'stripped of quality'.
Mechanisms that could explain the apparent quantitative imbalance between the observed sedimentation rates of carbon and the requirements of the benthos include (1) the horizontal transport (focusing) of organic material from adjacent areas and (2) the 'bouncing back' of the previously settled material (local resuspension). In the present study area, the amount of horizontally moving, resuspended matter is probably high in the ca $45 \mathrm{~m}$ layer that remained between the trap at $80 \mathrm{~m}$ and the bottom, providing the benthos with an 'extra' input of food. A turbid bottom water column reaching the upper depth of ca $80 \mathrm{~m}$ has been observed in the study area (Fukuda 1960), while notably strong water currents and a turbid benthic boundary layer $5 \mathrm{~m}$ above the bottom were registered by Marmefelt (1994). Thus, gross deposition on the site is probably much greater than that indicated by the $80 \mathrm{~m}$ trap

\section{Mineralization potential of the amphipod population}

The importance of benthic organisms in nitrogen mineralization, either by direct metabolism or by enhancing bacterial activity via bioturbation is well known. For benthic amphipods, Gardner et al. (1987) estimated the excretion of an abundant Diporeia spp. population to comprise up to $42 \%$ of total benthic nitrogen release in Lake Michigan. Henriksen et al. (1983) showed that excretion by the amphipod Corophium volutator could account for $80 \%$ of the net $\mathrm{NH}_{4}^{+}$ flux from the sediment and provide nitrifying bacteria with an important source of $\mathrm{NH}_{4}^{+}$. Moreover, bioturbation by $C$. volutator has also been shown to enhance benthic denitrification rates (Pelegrí \& Blackburn 1994, Pelegrí et al. 1994).

Evidently, excretion by the Monoporeia affinis population (Table 5) plays an important role in benthic nitrogen dynamics of the study area. Daily release varied markedly according to season [9 to $179 \mu \mathrm{mol}$ (0.13 to $\left.2.51 \mathrm{mg}) \mathrm{m}^{-2} \mathrm{~d}^{-1}\right\}$, but in summer/autumn it was above the averages found in other areas of the Baltic Sea [up to $237 \mu \mathrm{mol}(3.32 \mathrm{mg}) \mathrm{m}^{-2} \mathrm{~d}^{-1}$; Lehtonen 1995]. The estimated annual total respiration $(14.4$ to $17.1 \mathrm{~g}$ $\mathrm{C} \mathrm{m}^{-2} \mathrm{yr}^{-1}$ ) recorded was somewhat higher than that recorded by Bergström \& Sarvala (1986) for a coastal M. affinis population $\left(11.9 \mathrm{~g} \mathrm{C} \mathrm{m}^{-2} \mathrm{yr}^{-1}, 31 \%\right.$ of total benthic respiration), although the summer temperature in that area reached $18^{\circ} \mathrm{C}$. With regard to amphipods from the Gulf of Riga, considerably lower annual mineralization rates of both carbon and nitrogen have been recorded, due mainly to lower population densities in the area (Lehtonen unpubl.).

In the study area, seasonal variations in the mineralization potential of the amphipod population were 
mostly determined by biomass and, to a lesser extent, the density of the population, since the size of the amphipods varied markedly during the year (cf. Lehtonen 1995). In summer/autumn the growth of the amphipods is intense, and a marked elevation in the metabolism of the population was observed. The increase in the $\dot{V} \mathrm{NH}_{4}^{+}$(by $22 \%$ ) in summer is far less distinct compared to variations in $\dot{V} \mathrm{NH}_{4}^{+}$, which show a ca 7 -fold elevation (Lehtonen 1996b). In conclusion, the physiological condition of the amphipods (strong seasonal variations in the $\dot{V} \mathrm{NH}_{4}^{+}$), which is affected by seasonally changing food conditions, is an important regulator of the annual nitrogen release of this amphipod population.

\section{Nutrition and recruitment success as sources of interannual variations in population size}

Monoporeia affinis collected in winter and spring 1991 were markedly smaller than at a corresponding time in 1992 and 1993 (Fig. 6). Also the seasonally characteristic biochemical condition of the amphipods was almost identical in spring 1992 and 1993, indicating a healthier physiological state than in spring 1991 (Lehtonen 1996a). It appears that 1990 was nutritionally unfavourable for the amphipods in this area. Whether this was due to a lower sedimentation rate, or the fact that the density of the population was close to its peak with respect to the observed interannual cyclicity (Fig. 9) causing high intraspecific competition for food, or both of these, is speculative. Indications of the presence of the latter mechanism have been obtained in earlier studies (e.g. Elmgren 1978, Sarvala 1986, Maximov 1997) and are discussed further below.

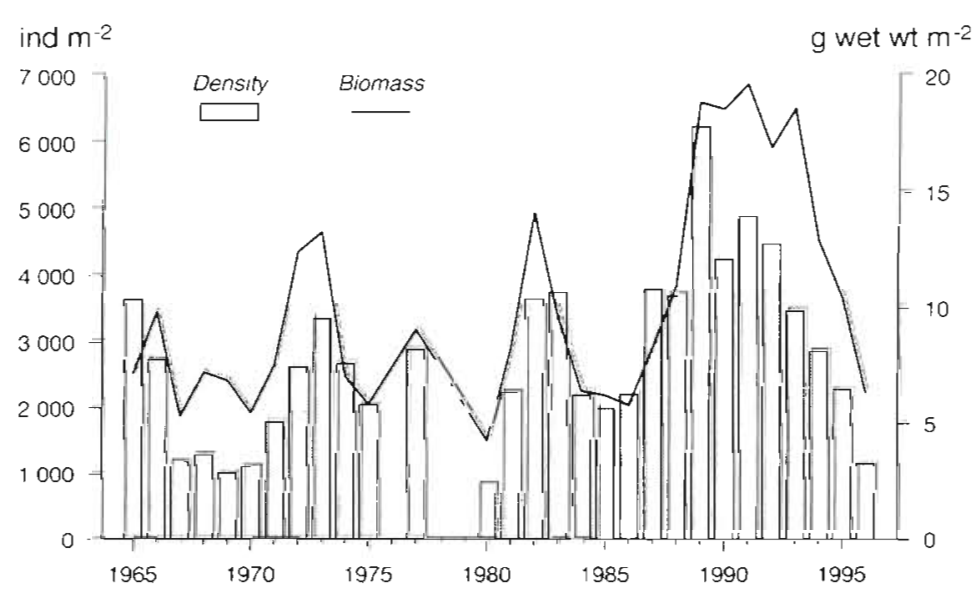

Fig. 9. Monoporela affinis. Long-term oscillations in the density and biomass of the population at the study station SR5 between 1965 to 1996
In the late summer of all the study years the lipid levels of Monoporeia affinis were close to the maximum values recorded for amphipods (Gardner at al. 1985, Lehtonen 1996a), regardless of marked variation in the productivity of the population (Fig. 8). This is not surprising since the abundance and biomass showed a decreasing trend through the study years, leaving, potentially, more food available for a smaller population to exploit. Interannual variations in the input of particulate organic matter and variations in population density result in differing amounts of food available to organisms per capita. It is apparent that the available quality food is utilized efficiently each year, but the overgrowth of the population ultimately results in a reduced survival of the young and a subsequent decrease in population size.

Remarkably, the proportion of the sedimented carbon assimilated by the amphipod population during the 'active period' was similar (ca 50\%) in both 1991 and 1993 (Table 4), despite the fact that in 1993 the population density and sedimentation rates were 49 and $58 \%$, respectively, of the values recorded in 1991 . This suggests that, at this site, the amphipods consume a constant proportion of the material that settles. Since good quality food material is effectively assimilated or 'stripped of quality' by benthic organisms, it is likely that, even during 1991, the most favourable year regarding sedimentation, the quality of food would not remain high throughout the summer.

Would the $50 \%$ assimilation rate have remained the same if the sedimentation in 1993 had been as high as in 1991? The $2+$ yr olds rapidly attained their maximum size (and lipid content); the small young-of-the-year, even with elevated growth rates, are unlikely to be able to consume but a small portion of the remainder. Then, the group with the greatest potential to deplete and benefit from the 'extra' food would be the $1+y r$ olds. It is likely that the meiofauna and bacteria consume the material not taken up by the amphipods. Thus, intensive competition for nourishment between the groups of organisms leads to rapid depletion of the settled good quality food.

The recruitment success of the young-ofthe-year is another potentially important element in regulating the population size of Monoporeia affinis. With the 'r-strategists' the survival of the offspring and their subsequent inclusion to the population as a distinct cohort represents a crucial step; even a minor increase in the proportion of the original offspring surviving a high-mortality period may result in a distinctly more abundant cohort (Valiela 1984, review by Gosselin \& Qian 1997). 
In the present study, the survival rate of the offspring was considerably higher in 1991 (56\%) compared to $1992(12 \%)$, although the population density was lower in 1992 (Figs. 3b \& 5), which strongly implies better availability of food in 1991. Furthermore, the latter cohort had a distinctly low FI (Fig. 7) and continued to decrease in abundance towards its second summer. In 1993, the theoretical offspring production was about double (due to a higher fecundity; Fig. 4), while the population density was about half of that recorded in 1991 (Fig. 3b). However, despite the fact that the sedimentation of carbon (between 15 April and 14 July) in 1993 (8.1 g C m² : Table 4) was markedly lower than in 1991 ( $13.9 \mathrm{~g} \mathrm{C} \mathrm{m}^{-2}$ ), the proportion of the number of offspring that survived until late summer was considerably higher (38\%) than in 1992, although clearly lower than in 1991 (56\%) (Fig. 5). This indicates that densitydependent control of Monoporeia affinis population size through competition for food (Sarvala 1986, Maximov 1997), especially as such competition reduces recruitment success, is a valid hypothesis for explaining the interannual variations in this amphipod population. Corroborating this interpretation, the negative effect of a high density, and of the presence of older generations, on the survival and growth of the young-of-theyear of $M$. affinis has been experimentally demonstrated by Hill (1992).

The decline in the survival rate of the cohort born in 1992 was distinct and coincided with very high offspring output and high population density (Figs. 3b \& 5). It is suggested that competition for food was very intense during the late spring and early summer, leading to rapid exhaustion of the newly settled matter. Observations on the greatly reduced lipid accumulation rate in both $1+$ and $2+$ yr olds between mid-June and early autumn 1992, compared to 1991 and 1993 (Lehtonen 1996a), indicate that quality food was sparse from mid-June onwards. Density-dependent regulation of population size appears to be the most obvious mechanism affecting the survival rate; however, since sedimentation (gross deposition) of organic matter may have been less during 1992 and/or more concentrated than in 1991 and 1993 (due possibly to different weather and hydrodynamic conditions) it may have had a crucial effect on the dynamics of the amphipod population.

The number of eggs per female was ca $1 / 3$ lower than would be expected using the female length versus egg number power regression by Cederwall (1977; also used by Sarvala 1986), and led to a substantially smaller number of potential offspring output at the study station. The marked interannual differences in the size of the gravid females (Fig. 4a) were later manifest in the variations in the potential number of offspring. A lower fecundity of the amphipods at the present open-sea station is conceivable, because of the poor food conditions compared to the coastal areas. In Cederwall's (1977) 2 yr study in the coastal Askö area, survival of the newborn was between 17 and $28 \%$; the maximum survival rate recorded in the present study (1991: 56\%), albeit probably a slight overestimation, was much higher. Even in the low-diversity Baltic Sea, coastal communities are usually more species-rich (e.g. Ankar \& Elmgren 1975, Elmgren 1984), with more intense interspecific competition for food and predation pressures. Together with severe temperature fluctuations these are factors that could be reducing the survival rate of the newborn, 'cancelling out' the observed higher fecundity of the coastal populations compared to open-sea populations.

Although the method used in the present study for estimating offspring survival may be considered somewhat unrefined, clear implications of interannual, density-dependent variations in the recruitment success of different annual cohorts are evident. In conclusion, a feasible hypothesis linking food availability and density-dependent control of population size of Monoporeia affinis at this site is that, during a good year of food availability, competition for food with the older cohorts (in this case, the $1+$ and $2+$ yr olds) faced by the young-of-the-year is greatly alleviated, and the prospect of the young passing the bottleneck of recruitment is increased, resulting in a marked elevation in population size.

\section{Observations relating to long-term oscillations}

This Monoporeia affinis population, monitored frequently since 1965 (Fig. 9), shows long-term oscillations (Andersin et al. 1978, 1984), which, as discussed above, are likely to be connected to variations in nutritional conditions, directly or through competition for food. Predation by fish has been suggested to be a major force in regulating the population size of benthic amphipod populations in lakes (e.g. McDonald et al. 1990). However, in the study area, predation by demersal fish (and the isopod Saduria entomon) is unlikely to cause the observed long-term interannual variability; the variations show an oscillating character with long intervals (ca $7 \mathrm{yr}$ ) between peaks and troughs, and, in the case of direct coupling, one would expect to find similar cycles also in the predator populations. Furthermore, despite a distinct seasonal cyclicity in the mean size of the individuals, no abrupt decreases that reflect size-selective predation can be seen in the relative abundance of the size classes (except changes that are obviously related to reproduction).

No direct links between the observed long-term fluctuations in the Monoporeia affinis populations and 
environmental biotic or abiotic variables could be established. Interannual variability in hydrographical conditions (salinity, temperature) have not been observed to coincide with the population fluctuations (Andersin et al. 1984). Interannual variations in primary production in the Bothnian Sea are not well known, but they are presumably rather weak (e.g. earlier compilation by Elmgren 1978, Lassig et al. 1978, Larsson \& Hagström 1982. Andersson et al. 1996), while no comparable data on variations in sedimentation rates are available. Nevertheless, it is perfectly clear that the observed variations in population size and the survival of the young are associated with changes in benthic nutritional conditions, either directly or through intraspecific competition for food.

It is highly probable that the observed variations in the survival rate of offspring have far-reaching consequences for the development of long-term abundance fluctuations in this area. A smaller cohort will produce less offspring, with a time lag of $3 \mathrm{yr}$; meanwhile, its low abundance will reduce intraspecific competition with the following generations during the next $2 \mathrm{yr}$, thus potentially increasing their survival rate. Since the amphipods at the study site have a 3 yr life-cycle, the recovery of the population, once reduced, is slow.

It is suggested that even though the amount of available food sets the ultimate limits on population growth, and critical density where density-dependent food competition exerts a significant effect, it does not remain the primary regulating factor once population density has started to decline. Thus, between-year irregularities in food concentration, assuming that they remain within the amplitudes that characterize the area, have little effect on the amphipod population in its low-density stage; however, these irregularities may have a marked effect when amphipod abundance has increased close to or over the critical carrying capacity of the ecosystem.

Acknowledgements. The authors express their gratitude to Dr J.-M. Leppänen for the sedimentation data and critical comments on the manuscript. Ms T Vartio performed the chem1cal analysis of trap material. The zoobenthos samples were analysed by Ms R. Ahlsten. The staffs of the RV 'Aranda' as well as the Department of Biological Oceanography of the Finnish Instutute of Marine Research are thanked for assistance in sampling. Mr Richard Thompson Coon (Gulf of Finland Environment Society) is thanked for critical proof-reading of the final manuscript.

\section{LITERATLRE CITED}

Andersin AB, Lassig J, Parkkonen L, Sandler H (1978) Longterm fluctuations of the soft bottom macrofauna in the deep areas of the Gulf of Bothnia 1954-1974, with special reference to Pontoporeia affinis Lindstrom (Amphipoda) Finn Mar Res 244:137-144
Andersin AB, Lassig J, Sandler H (1984) On the biology and production of Pontoporeia affinis Lindstr. in the Gulf of Bothnia. Limnologica 15:395-401

Andersin $A B$, Lassig J, Sandler H (1986) Rationaluzation of zoobenthic monitoring methods. Baltic Sea Envuron Proc 19:23.3-245

Andersson A, Hajdu S, Haecky P, Kuparinen J, W1kner J (1996) Succession and growth limitation of phytoplankton in the Gulf of Bothnia (Baltic Sea). Mar Biol 126:791-801

Ankar S (1977) The soft bottom. ecosystem of the northern Baltic Proper with special reference to the macrofauna. Contrib Askö Lab 19:1-62

Ankar S, Elmgren R (1975) A survey of the benthic macroand meiofauna of the Askö-Landsort areat. Merentutkimuslait Julk/Havsforskningsinst Skr 239:257-264

Anonymous (1988) Baltic Marine Environment Protection Commission-Helsinki Commission: guidelines for the Baltic Monitoring Programme for the third stage, part B. Chemical and physical determinands. Baltic Sea Environ Proc 27 B, $161 \mathrm{p}$

Bergström I, Sarvala J (1986) Seasonal course of soft-bottom community respiration in a northern Baltic archipelago. Ophelia (Suppl) 4:17-26

Bousfield EL (1989) Revised morphological relationships within the amphipod genera Pontoporela and Gammaracanthus and the 'glacial relict' significance of their postglacial distributions. Can J Fish Aquat Sci 46:1714-1725

Brydsten L (1993) Characterization of transport bottoms in the Gulf of Bothnia-a model approach. Aqua Fenn 23 $153-164$

Cederwall H (1977) Annual macrofauna production of a soft bottom in the northern Baltic Proper. In: Keegan BF, Céidigh PÓ. Boaden PJS (eds) Biology of benthic organisms. Proc 11th Eur Mar Biol Symp, Galway, Ireland, 5-11 October, 1976. Pergamon Press, Oxford, p 155-164

Elmgren R (1978) Structure and dynamics of Baltic benthos communities, with particular reference to the relationship between macro- and meiofauna. Kiel Meeresforsch 4:1-22

Elmgren R (1984) Trophic dynamics in the enclosed, brackish Baltic Sea. Rapp P-V Réun Cons Int Explor Mer 183: $152-169$

Fitzgerald SA, Gardner WS (1993) An algal carbon budget for pelagic-benthic coupling in Lake Michigan. Limnol Oceanogr 38:547-560

Fukuda $M$ (1960) Transparency measurements in the Baltic Sea. Medd Oceanogr Inst Göteborg 27:1-18

Gardner WS, Nalepa TF, Frez WA, Cichocki EA, Landrum PF (1985) Seasonal patterns in lipid content of Lake Michigan macroinvertebrates. Can J Fish Aquat Sci 42:1827-1832

Gardner WS, Nalepa TF, Malczyk JM (1987) Nitrogen mineralization and denitrification in Lake Michigan sediments. Can J Fish Aquat Sci 32:1226-1238

Gosselin LA, Qian PY (1997) Juvenile mortality in benthic marine invertebrates. Mar Ecol Prog Ser 146:265-282

Graf $G$, Bengtsson W, Diesner U, Schulz R, Theede H (1982) Benthic response to sedimentation of a spring phytoplankton bloom: process and budget. Mar Biol 67:201-208

Heiskanen AS, Kononen K (1994) Sedimentation of vernal and late summer phytoplankton communities in the coastal Baitic Sea. Arch Hydrobiol 131:175-198

Heiskanen AS, Leppänen JM (1995) Estimation of export production in the coastal Baltic Sea: effect of resuspension and microbial decomposition on sedimentation measurements. Hydrobiologia 316:211-224

Henriksen K, Rasmussen MB, Jensen A (1983) Effect of bioturbation on microbial nitrogen transformations in the sediment and fluxes of ammonium and nitrate to the over- 
lying water. Ecol Bull 35:193-205

Hill C (1992) Interactions between year classes in the benthic amphipod Monoporeia affinis: effects on juvenile survival and growth. Oecologia 91:157-162

Hill C, Quigley MA, Cavaletto JF, Gordon W (1992) Seasonal changes in lipid content and composition in the benthic amphipods Monoporeia affinis and Pontoporeia femorata. Limnol Oceanogr 37:1280-1289

Johnson RK, Wiederholm T (1992) Pelagic-benthic couplingthe importance of diatom interannual variability for population oscillations of Monoporeia affinis. Limnol Oceanogr $37: 1596-1607$

Kuparinen J, Leppänen JM, Sarvala J, Sundberg A, Virtanen A (1984) Production and utilization of organic matter in a Baltic ecosystem off Tvärminne, southwest coast of Finland. Rapp P-V Réun Cons Int Exp Mer 183:180-192

Larsson U, Hagström $\AA$ (1982) Fractionated phytoplankton primary production, exudate release and bacterial production in a Baltic eutrophication gradient. Mar Biol 67:57-70

Lassig J, Leppänen JM, Niemi Å, Tamelander G (1978) Phytoplankton primary production in the Gulf of Bothnia in 1972-1975 as compared with other parts of the Baltic Sea. Finn Mar Res 244:101-115

Lehtonen KK (1995) Geographical variability in the bioenergetic characteristics of Monoporeia/Pontoporeia spp. populations from the northern Baltic Sea, and their potential contribution to benthic nitrogen mineralization. Mar Biol 123:555-564

Lehtonen KK (1996a) Ecophysiology of the benthic amphipod Monoporeia affinis in an open-sea area of the northern Baltic Sea: seasonal variations in body composition, with bioenergetic considerations. Mar Ecol Prog Ser 143:87-98

Lehtonen KK (1996b) Ecophysiology of the benthic amphipod Monoporeia affinis in an open-sea area of the northern Baltic Sea: seasonal variations in oxygen consumption and ammonia excretion. Mar Biol 126:645-654

Leonardsson K, Sörlin T, Samberg H (1988) Does Pontoporeia affinis (Amphipoda) optimize age at reproduction in the Gulf of Bothnia? Oikos 52:328-336

Leppänen JM (1988) Cycling of organic matter during the vernal growth period in the open northern Baltic proper VI. Sinking of particulate matter. Finn Mar Res 255:97-118

Leppänen JM, Bruun JE (1988) Cycling of organic matter during the vernal growth period in the open northern Baltic proper. IV. Ciliate and mesozooplankton species composition, biomass, food intake, respiration, and production. Finn Mar Res 255:55-78

Marmefelt E (1994) Currents in the Gulf of Bothnia during the field year of 1991. SMHI Reports Oceanography 19. Norrköping, Sweden, p 1-46

Maximov AA (1997) Monoporeia affinis population dynamics in the eastern Gulf of Finland. In: Andrushaitis $A$ (ed) Proc 13th Symp Baltic Mar Biol. Institute of Aquatic Ecology, University of Latvia, p 121-126

McDonald ME, Crowder LB, Brandt SB (1990) Changes in Mysis and Pontoporeia populations in southeastern Lake

Editorial responsibility: Otto Kinne (Editor),

Oldendorf/Luhe, Germany
Michigan: a response to shifts in the fish community. Limnol Oceanogr 35:220-227

Mohammadi M, Karjala L. Kuparinen J (1993) Number, biovolume and biomass of bacterid in the mud sediment of the Bothnian Sea. Aqua Fenn 23:201-208

Moore JW (1979) Ecology of a subarctic population of Pontoporeia affinis Lindström (Amphipoda). Crustaceana 36: 267-276

Pelegri SP, Blackburn TH (1994) Bioturbation effects of the amphipod Corophium volutator on microbial nitrogen transformations in marine sediments. Mar Biol 121. $253-258$

Pelegrí SP, Nielsen LP, Blackburn TH (1994) Denitrification in estuarine sediment stimulated by the irrigation activity of the amphipod Corophium volutator. Mar Ecol Prog Ser $105: 285-290$

Peters RH (1983) The ecological implications of body size. Cambridge University Press, Cambridge

Riley GA (1956) Oceanography of Long Island Sound, 1952-1954. IX. Production and utilization of organic matter Bull Bingham Oceaonogr Collect, Yale Univ 15: $324-344$

Sarvala J (1986) Interannual variation of growth and recruitment in Pontoporeia affinis (Lundstrom) (Crustacea: Amphipoda) in relation to abundance fluctuations. J Exp Mar Biol Ecol 101:41-59

Segerstråle SG (1937) Studien über die Bodentierwelt in südfinnländischen Küstengewässern III. Zur Morphologie und Biologie des Amphipoden Pontoporeia affinis, nebst einer Revision der Pontoporeia-Systematik. Soc Sci Fenn Comment Biol 7:1-181

Siegfried CA (1985) Life history, population dynamics and production of Pontoporeia hoyi (Crustacea, Amphipoda) in relation to the trophic gradient of Lake George, New York. Hydrobiologia 122:175-180

Smetacek VS (1985) Role of sinking in diatom life-history cycles: ecological, evolutionary and geological significance. Mar Biol 84:239-251

Smetacek V, von Bröckel K, Zeitzschel B, Zenk W (1978) Sedimentation of particulate matter during a phy̧toplankton spring bloom in relation to the hydrographical regime. Mar Biol 47:211-226

Uitto A, Sarvala J (1991) Seasonal growth of the benthic amphipods Pontoporeia affinis and P. femorata in a Baltic archipelago in relation to environmental factors. Mar Biol 111:237-246

Valiela I (1984) Marine ecological processes. Springer Verlag, New York

Viitasalo M (1994) Seasonal succession and long-term changes of mesozooplankton in the northern Baltic Sed. Finn Mar Res 263:1-39

Wassmann P (1984) Sedimentation and benthic mineralization of organic detritus in a Norwegian fjord. Mar Biol 83:83-94

Zeitzschel B, Diekmann P, Uhlmann L (1978) A new multisample sediment trap. Mar Biol 45:285-288

Submitted: November 6, 1997; Accepted: April 4, 1998

Proofs received from author(s): June 9, 1998 